\title{
Erratum: Pouring over liquid handling
}

\section{Vivien Marx}

Nat. Methods 11, 33-38 (2014); published online 30 December 2013; corrected after print 13 January 2014

In the version of this article initially published, the text stated that Toby Jenkins directs liquid handling for instrument manufacturer TTP Labtech. This name was misspelled; the correct name is Joby Jenkins. The error has been corrected in the HTML and PDF versions of the article.

\section{Erratum: Dissecting genomic diversity, one cell at a time}

Paul C Blainey \& Stephen R Quake

Nat. Methods 11, 19-21 (2014); published online 30 December 2013; corrected after print 27 January 2014

In the version of this article initially published, references $16-24$ were incorrectly cited as references $15-23$. The error has been corrected in the HTML and PDF versions of the article.

\section{Corrigendum: Using networks to measure similarity between genes: association index selection}

Juan I Fuxman Bass, Alos Diallo, Justin Nelson, Juan M Soto, Chad L Myers \& Albertha J M Walhout

Nat. Methods 10, 1169-1176 (2013); published online 26 November 2013; corrected after print 27 January 2014

In the version of this article initially published, the formula describing the connection specificity index (CSI) in Box 2 was incorrect. The denominator in the fraction of the CSI equation originally read " $n_{\mathrm{y}}$ "; the correct denominator is "\# of X-type nodes in the network." The error has been corrected in the HTML and PDF versions of the article.

\section{Corrigendum: Quantifying cell-generated mechanical forces within living embryonic tissues}

Otger Campàs, Tadanori Mammoto, Sean Hasso, Ralph A Sperling, Daniel O’Connell, Ashley G Bischof, Richard Maas, David A Weitz, L Mahadevan \& Donald E Ingber

Nat. Methods 11, 183-189 (2014); published online 8 December 2013; corrected after print 5 February 2014

In the version of this article initially published, the current affiliation of author Ralph Sperling was not included. His current affiliation is the Fraunhofer ICT-IMM, Mainz, Germany. The error has been corrected in the HTML and PDF versions of the article.

\section{Erratum: Singled out for sequencing}

Kelly Rae Chi

Nat. Methods 11, 13-17 (2014); published online 30 December 2013; corrected after print 5 February 2014

In the version of this article initially published, an incorrect institutional affiliation was given for Jie Wang: this affiliation was listed as Harvard when it should have been Peking University Cancer Hospital. The error has been corrected in the HTML and PDF versions of the article. 